hold office. A new check list of British mosses has been prepared by E. C. Wallace and P. W. Richards and will be published by the Society this year. It is hoped to hold meetings in 1951 in south-west Ireland and at Oxford.

\section{Control of the Horsetail, Equisetim arvense}

MeThoxone (2-methyl, 4-chloro-phenoxyacetic acid) has been used satisfactorily by G. R. Jackman and M. A. H. Tincker to kill the green top-growth of common horsetail (J. Roy. Hort. Soc., 74, Pt. 8; Aug. 1949). Standard preparations of 'Agroxone' were used at $6 \mathrm{oz}$. per sq. yard. Applications in late May killed the green shoots for the season; but treatment in succeeding years is necessary to reduce the activity of the underground stems. Many garden plants, including dahlias, lupins and several conifers, were not damaged by the treatment. Others, for example, birch and Cotoneaster seedlings, were killed by it.

\section{Principles of Radio Valves}

A SERIES of attractive educational booklets, entitled "Electrons", is being published by the Edison Swan Electric Co., Ltd. (155 Charing Cross Road, London, W.C.2) ; the booklets, each in a different distinctive coloured cover, explain simply, by means of illustrations, diagrams and charts, the history and working principles of the radio valve. The first two of the series so far issued deal with the diode (red cover) and the triode (orange cover). Others to follow are : the screen grid (yellow), pentode (green), beam tetrode (blue), frequency changer (purple) and the multiple diode (grey). Copies of the booklets, as they are published, are available free to education authorities, radio societies and other bodies.

\section{Pacific Science Association}

Following a decision made at the Seventh Pacific Science Congress held in New Zealand last year, a permanent secretariat of the Pacific Science Association has now been established in the Bernice P. Bishop Museum, Honolulu, for the purpose of maintaining the activities of the Association during the periods between congresses. Mr. Loring G. Hudson, recently information officer with the South Pacific Commission in New Caledonia, has been appointed executive secretary of the secretariat, and Miss Brenda Bishop, recently secretarial assistant for the Seventh Pacific Science Congress, is assistant secretary.

\section{Public Health Laboratory Service Board}

Since 1946, when the Public Health Laboratory Service was placed on a permanent basis, the Medical Research Council has continued to administer it as the agent for the Ministry of Health. It has been decided that the Council will, with certain reservations on matters of broad policy, now delegate this function to a Public Health Laboratory Service Board, composed in the first instance as follows : Dr. A. Landsborough Thomson (chairman), Prof. S. P. Bedson, Dr. C. Metcalfe Brown, Dr. A. N. Drury, Sir Percival Hartley, Sir W. Wilson Jameson (ex officio) and Dr. A. A. Miles, with Dr. W. H. Bradley as observer from the Ministry of Health.

\section{New Electron Microscope at Glasgow}

AN electron microscope has recently been installed in the Chemistry Building of the University of Glasgow. It is to be used, in conjunction with diffraction techniques, for a study of proteins and nucleo-proteins of biological interest. The instrument is under the care of Dr. I. M. Dawson, who has been appointed to an Imperial Chemical Industries fellowship. Dr. Dawson graduated at Glasgow in 1943, and then undertook researches there in photochemistry and X-ray crystallography. For the past two years he has been in charge of the electron microscopes at the National Institute for Medical Research, London.

\section{Society for the Bibliography of Natural History}

THE annual general meeting of the Society for the Bibliography of Natural History was held on April 24 . At the meeting it was stated that a bibliography of the American naturalist C. J. Maynard, by C. F. Batchelder, is in the press, and it is intended to issue shortly the first of a series of facsimiles of rare or unpublished works. This will be part of a MS. notebook dealing with Linnæus's entomological lectures. Formal business was followed by a lecture on the "Medieval Bestiary", by Dr. Beatrice M. I. White. Officers of the Society were elected as follows : President, Dr. J. Ramsbottom ; Honorary Secretary and Treasurer, Mr. A. C. Townsend; Committee, Mr. W. N. Edwards, Dr. F. C. Fraser, Mr. F. J. Griffin, Mr. Francis Hemming, Mr. W. T. Stearn and Mr. C. Kirke Swann.

\section{Announcements}

Str Harold Harteley, president of the British Association, has had conferred on him the honorary degree of D.C.L. by the University of Oxford.

Mr. H. HAYHURST has been elected president of the Manchester Literary and Philosophical Society on the retirement of Dr. E. J. F. James. Mr. Hayhurst will combine the two offices of president and honorary treasurer of the Society.

The 1950 annual May lecture of the Institute of Metals will be given at the Royal Institution, Albemarle Street, London, W.1, on May 10, at 6 p.m., by Dr. H. Roxbee Cox, chief scientist, Ministry of Fuel and Power, his subject being "Industrial Gas Turbines". The lecture is open to the general public.

Ar the anniversary meeting of the members of the Royal Institution held on May 1 the following officers were elected : President, Lord Brabazon of Tara; Secretary, Prof. A. O. Rankine ; Treasurer, Dr. R. E. Slade.

THE Fifth International Congress of Scientific Research and the Social Fight against Cancer will take place at the Sorbonne, Paris, during July 15-22, under the presidency of Prof. A. Lacassagne, director of the Paris Radium Institute. At least fifty countries will be represented. Further particulars can be obtained from the secretary-general of the Congress, Prof. V. Le Lorier, 6 Avenue Marceau, Paris 8.

THE British Welding Research Association is offering a prize of $£ 100$ for an original unpublished paper on a research into wolding or its application, carried out in Great Britain or Northern Ireland. Authors must be less than thirty-five years old and must limit their papers to less than five thousand words. The prize is financed by the British Oxygen Co. and was first offered in 1948. Papers must be submitted by September 30 to the Secretary, British Welding Research Association, 29 Park Crescent, London, W.1. 